\title{
Çocuklarda Periton Diyalizi Enfeksiyonlarının Önlenmesi
}

\section{Prevention of Peritoneal Dialysis Infections at Children}

\author{
Ayşegül YILDIZ ${ }^{1}$, Seda ŞAHAN ${ }^{2}$
}

${ }^{1}$ Ögretim Görevlisi, Kapadokya Üniversitesi, Kapadokya Meslek Yüksekokulu, Diyaliz Programı. Nevşehir, Türkiye

${ }^{2}$ Araştırma Görevlisi, Bakırçay Üniversitesi, Sağlık Bilimleri Fakültesi, Hemşirelik Bölümü. İzmir, Türkiye

* Bu çalışma 7 Mart 2020 tarihinde Ürgüp’te düzenlenen Multidisipliner Yaklaşımla Yenidoğan konulu I. Kapadokya Üniversitesi Sağlık Sempozyumu'nda sözel bildiri olarak sunulmuştur.

Geliş Tarihi: 11 Nisan 2020

Kabul Tarihi: 22 Mayss 2020

\section{İletişim / Correspondence:}

Ayşegül YILDIZ

\section{E-posta:}

aysegul.yildiz@kapadokya.edu.tr

\section{Özet}

Periton diyalizi, son dönem böbrek yetmezliği olan çocukların, böbrek fonksiyonlarını sürdürebilmeleri amacıyla dünya çapında kullanımı giderek artan ve hastaların tedavisinde olumlu sonuçlar alınmasını sağlayan bir yöntemdir. Periton diyalizi işlemi aile ve çocuk için konforlu ve yaşam aktivitelerini ciddi ölçüde etkilemeyen bir tedavi yöntemidir. Buna rağmen periton diyalizi işlemindeki temel kurallara uyulmadığı takdirde ise ciddi sorunlar meydana gelebilmektedir. Periton diyalizi işleminde peritonit, kateter giriş-çıkış yeri enfeksiyonu, kateter tünel enfeksiyonu, karın ağrısı, kateterin tıkanması, protein yetersizliği, diyaliz sıvısıyla birlikte kan gelmesi gibi komplikasyonlar meydana gelebilmektedir. Bu komplikasyonlar değerlendirildiğinde ise en önemli komplikasyon olarak enfeksiyonlar karşımıza çıkmaktadır. Bu çalışmada periton diyalizi tedavisi alan çocuk hastalarda sık görülen enfeksiyonları önlemek amacıyla alınabilecek önlemlerin tanımlanması amaçlanmıştır. Bu amaçla Pubmed, Google Akademik, Academia ve Cochrane veri tabanlarında taranan konuya uygun 13 adet ilgili literatür eşliğinde periton diyalizi tedavisi alan çocuk hasta grubunda ortaya çıkan enfeksiyonların önlenmesi için yapılması gerekenler gözden geçirilmiştir.

Anahtar Kelimeler: Çocuk; Periton Diyalizi; Enfeksiyon.

\begin{abstract}
Peritoneal dialysis is a method that is used worldwide to maintain kidney function of children with end-stage renal failure and provides positive results in the treatment of patients. Peritoneal dialysis procedure is a comfortable treatment for the family and child and does not significantly affect the life activities. However, serious problems may arise if the basic rules in the periteonal dialysis process are not followed. Periteonal dialysis procedure could have complications such as peritonitis, catheter entry-exit site infection, catheter tunnel infection, abdominal pain, catheter occlusion, protein deficiency, and blood supply with dialysis fluid. When these complications are evaluated, infections are the most important complication. In this study, it is aimed to define the measures that can be taken to prevent common infections in pediatric patients receiving periteonal dialysis treatment. For this purpose, 13 necessary literature appropriate to the subject scanned in Pubmed, Google Academic, Academia, and Cochrane databases, along with related literature, have been reviewed to prevent infections that occur in the pediatric patient group.
\end{abstract}

Keywords: Child; Peritoneal Dialysis; Infection. 


\section{GİRIŞ}

Son dönem böbrek yetmezliği olan çocukların, böbrek fonksiyonlarını sürdürebilmeleri için hemodiyaliz (HD), periton diyalizi (PD) ve renal transplantasyon gibi tedavi seçenekleri uygulanmaktadır $(1,2)$.

Günümüzde PD yönteminin tercih edilme oran1 dünya çapında artmakta, böbrek yetmezliği tanısı alan çocuk hastaların tedavisinde olumlu sonuçlar elde edilmektedir (2, 3). PD hizlı uygulanabilmesi, fazla araç gereç gerektirmemesi, ucuz olması ve güvenli bir yöntem olması sebebiyle çocuklarda siklıkla tercih edilmektedir $(4,5)$.

PD işlemi hastanın periton boşluğuna belirli aralıklarla diyaliz sıvısı verip toksik ve metabolik ürünlerin bu sıvıya geçip elektrolit dengesinin sağlanması için bir süre bekletildikten sonra geri alınması ilkesine dayanan bir yöntemdir $(2,5)$. Periton yüzeyi kan damarlarından zengin bir doku olduğundan diyaliz işleminin gerçekleştirilmesinde ideal bir membran olarak kullanılmaktadır (5).

Evde gerçekleştirilen bir yöntem olması nedeniyle PD çocuk hastalara büyük ölçüde özgürlük kazandırmakta ve hastalar sadece aylık kontrolleri için diyaliz merkezlerine gitmektedir. Ancak çocukların bakımından ailesi sorumlu olduğu için ailenin PD ile ilgili eğitilmesi ve hastanın evde ziyaret edilmesi gerekmektedir (5). PD ile ilgili verilecek olan aile eğitiminde, tedavi planı, işlemin teknik özellikleri, hastalığın psikolojik etkileri, diyaliz öncesi ve sonrası hastada meydana gelen değişiklikler, torbanın nasıl değiştirileceği gibi konu başlıklarına yer verilmelidir. Eğer çocuk sorumluluk alabilecek yaştaysa mutlaka çocuğa yapılan işlemlerle ilgili sorumluluk verilmelidir (5).

\section{Periton Diyalizine Bağlı Gelişen Enfeksiyonlar}

PD işleminde peritonit, kateter giriş-çııış yeri enfeksiyonu, kateter tünel enfeksiyonu, karın ağrısı, kateterin tıkanması, protein yetersizliği, diyaliz sıvısıyla birlikte kan gelmesi gibi kompli- kasyonlar meydana gelebilmektedir. Bu komplikasyonlar değerlendirildiğinde ise en önemli komplikasyon olarak enfeksiyonlar karşımıza çıkmaktadır $(3,4)$. Peritonit ve kateter giriş-çıkış yeri enfeksiyonları hastaların hastaneye yatışının en sık nedenidir. Periton diyalizi kateterinin çıkış yeri steril olmadığından bu bölgedeki enfeksiyon peritonite neden olmaktadır. Diyaliz tedavisi sırasında periton boşluğuna verilen sıvı peritondaki savunma mekanizmalarını ve peritoneal ortamı bozmaktadır. Boşaltma işlemi sonucunda makrofaj ve opsonin kaybi olmaktadır. Bu nedenlerle çok az sayıda bakteri bile periton diyalizi hastalarında enfeksiyona yol açabilmektedir (6). PD ile ilgili eğitim yetersizliği, kateter yerleştirme işlemi sırasında antisepsinin bozulması, kişide antibiyotik direnci gelişmesi, S. aureus taşıyıcılığ gibi nedenler kateter giriş yerinde enfeksiyon gelişmesine zemin hazırlayan risk faktörleridir (7).

Kateterle ilişkili enfeksiyonlarda etkenler, S. aureus, S. epidermidis, Pseudomonas olarak karşımıza çıkmaktadır. $\mathrm{Bu}$ bölgede enfeksiyon gelişimini tespit etmek için kateter bölgesi ve çevresi, hassasiyet, kızarıklık, şişlik, pürülan akıntı yönünden gözlenmelidir $(1,8)$.

Kateter tünel enfeksiyonu; Peritondan çıkan kateterin çıkış yerine kadar olan kısmını içine alan deri altı yoluna 'Kateter Tüneli' ismi verilmektedir. Kateter tünelinde enfeksiyona neden olan etkenler genellikle Stafilokok türündeki ajanlardır. Kateter tünelinde enfeksiyon oluştuğunda ortaya çıkan belirti ve bulgular, cilt altı tünel boyunca kalınlaşma ve düzensizlik, tünel segmenti üzerinde kızarıklık, tünel boyunca ağrı ve hassasiyet, tünel içinde kateter gevşekliği, tünel üzerinde apse, çıkış yerinden bol akıntıdır $(1,5)$.

Diyaliz setinin peritoneal katetere takılıp çıkarılmas1 sırasında yetersiz steril teknik kullanılması nedeniyle peritonit gelişir. Peritonit geliştiğinde hastada karın ağrısı, vücut 1sısında artma, bulant1kusma, titreme, konstipasyon ve diyare gibi semptomlar görülebilmektedir. Ortaya çıkan bulgular ise ateş yüksekliği, diyalizatta bulanık- 
l1k, rebound fenomeni, karında hassasiyet, kanda ve periton sivisında lökositozdur. Bu komplikasyonları erken dönemde belirleyebilmek için karında hassasiyet ve gelen sıvının özellikleri iyi izlenmelidir $(1,8)$.

\section{PD Bağlı Enfeksiyonların Önlenmesi için Yaklaşımlar}

Periton diyaliziyle ilişkili ortaya çıkan enfeksiyonların öncelikle türü, sıklığı, nedenleri araştırılmalıdır. Enfeksiyon gelişen çocuklarda, periton diyalizi tekniği gözden geçirilmelidir. Hastanın ve ailesinin ihtiyaç duyduğu konulara ilişkin, periton diyaliz hemşiresi tarafından eğitimler verilmelidir. Bunlara ek olarak enfeksiyonlardan korunma için profilaktik tedaviler de önerilmektedir (9).

\section{Kanita dayalı uygulamalar}

Güvenli PD uygulaması gerçekleştirebilmek için kateter yerleştirilmesinden önce intravenöz anti- biyotik uygulamasının erken postoperatif peritonit oluşumunu önlediği kanıtlanmıştır. Topikal mupirosin kullanılarak $S$. aureus burun taşıyıcıl1ğının ortadan kaldırılmasının çıkış yeri/tünel enfeksiyonları riskini ve peritonit riskini azalttığ bildirilmiştir $(6,10)$.

Kateter çıkış yerinde rutin mupirosin uygulaması, S.aureus enfeksiyonu riski yüksek olan tüm PD hastaları için önerilmektedir. Ayrıca günlük gentamisin krem kullanımının hem kateter ilișkili enfeksiyonu hem de peritonit oranlarını azalttığ1 tespit edilmiştir $(6,10)$ (Tablo1).

\section{Hasta ve ailesinin ĕğitimi}

Farklı ve karmaşık hastalıklara sahip olan çocuklar, tıbbi durumlarının ortaya çıkardığı gelişimsel problemler ve psikososyal değişimler nedeniyle yüksek risk altındadır (15). Çocuğun yaşadığı geçici kısıtlamalar veya uzun süreli sakatlıklar, fonksiyonel sınırlamalara neden olmaktadır (16).

Tablo1. Periton Diyalizine Bağlı Gelişen Enfeksiyonları Önleme ile İlgili Öneriler

\begin{tabular}{|c|c|c|}
\hline \multicolumn{2}{|r|}{ Enfeksiyon Türü } & Önerilen yöntemler \\
\hline$\bullet$ & Peritonit & $\begin{array}{l}\text { *Düşük glukoz içerikli solüsyonların tercih edilmesinin peritonit gelişimini } \\
\text { azalttığı bildirilmiştir (11). } \\
\text { *A ğırlık ve boy persentillerinin normal değerlerinin altında olması ve serum } \\
\text { albümin düzeyinin düşük olmasının peritonite yatkınlığı arttırdığı bildirilmiş, } \\
\text { ağırlık, boy ve serum albümin düzeylerinin normal sınırlarda tutulmasının } \\
\text { peritonite yakalanma riskini azaltacağı ifade edilmiştir (12). } \\
\text { *Intraperitoneal amikasin ve vankomisin kullanımının peritonit gelişiminini } \\
\text { önlediği bildirilmiştir.(13) } \\
\text { *Peritonitli hastalarda intraperitoneal antibiyotik tedavisi uygulamasının } \\
\text { intravenöz antibiyotik tedavisi uygulamasına göre daha etkili bir yöntem } \\
\text { olduğu sonucuna ulaşılmıştır (14). } \\
\text { *Sürekli ve tekrarlayan hasta ve ailesinin eğitiminin peritonit gelişimini azalttığı } \\
\text { bildirilmiştir (10). }\end{array}$ \\
\hline$\bullet$ & $\begin{array}{l}\text { Kateter giriş-çıkış yeri } \\
\text { enfeksiyonu }\end{array}$ & $\begin{array}{l}\text { *Preoperatif intravenöz antibiyotik tedavisi uygulanmasının enfeksiyon } \\
\text { gelişimini önlediği bildirilmiştir (6). } \\
\text { *Kateter çıkış yeri bakımının enfeksiyon gelişimini önlemede önemli bir etken } \\
\text { olduğu tespit edilmiştir (7). } \\
\text { * Kateter çıkıs yerinde, povidone iyodin, klorheksidin kullanımı, lokal } \\
\text { antimikrobiyal bir ajan kullanılması tavsiye edilmektedir (14). } \\
\text { *Kateterin bakımı ve korunmasında hasta ve ailesinin eğitiminin önemli olduğu } \\
\text { bildirilmiştir (6). } \\
\text { *Kateter enfeksiyonunda eşlik eden tünel enfeksiyonu varsa kateterin çıarılması } \\
\text { önerilmektedir (7). }\end{array}$ \\
\hline
\end{tabular}


Çocuklar yetişkinlerden tüm yönleriyle farklıdır. Kronik hastalığa sahip olan çocuğun hastalığa uyumu farklılıkları göz önüne alınarak sağlanmalıdır. Çocuklar bakımlarının bir kısmı veya tamamı için ebeveynlerine ve bakıcılarına bağımlıdırlar. $\mathrm{Bu}$ nedenle pediatrik bakım neredeyse her zaman bir kişiden fazla bireyle gerçekleştirilir (17). Pediatrik hastalar, bilişsel, motor, dil, sosyal ve duygusal gelişim dönemi içerisinde hızla büyüyen bir süreçte yer alırlar. $\mathrm{Bu}$ nedenle pediatrik hastaların öz-yönetim kapasiteleri sürekli değişmektedir. $\mathrm{Bu}$ farklı olgunluk aşamalarında çocuğa, bulunduğu yaş dönemi özelliklerine göre eğitim ve sorumluluk verilmelidir. Pediatride öz-yönetimi sağlamak zordur, ebeveynler, bakıcılar veya çocuk özyönetimi paylaşmaktadır (18).

Çocuk ve ailesinin eğitimi PD enfeksiyonları için değiştirilebilir bir risk faktörü olarak tanımlanmaktadır (10). Eğitim planlanmasında çocuk ve aile birlikte ele alınmalıdır. Ailede çocuğun bakımıyla ilgilenen kişiler ve çocuğun bakıcısı da bu sürece dâhil edilmelidir. Ebeveynler içerisinde tek ebeveynin çocuğun bakımını üstlenmesindense her iki ebeveynin de sorumluluk alması gerekmektedir. Bu durumda bir ebeveyn çocuğun bakımıyla ilgilenemeyeceği zaman diğer ebeveyn bakımı üstlenebilir $(17,18)$. Çocuğun ve ailenin gereksinimlerine göre eğitim konuları çeşitlendirilebilir. Genel kapsamıyla eğitim içeriği, ön eğitim, periton diyalizi eğitimi ve sürekli eğitim şeklinde sınıflandırılabilir (1).

Son yıllarda teknolojinin hızla gelişmesi ile pediatrik hasta eğitiminde farklı materyal ve yöntemler kullanılmaktadır $(15,17)$. Bu eğitim yöntemleri içerisinde web tabanlı eğitim, animasyon videoları, online izlem, yazılı ve resim içerikli bilgiler, eğitim DVD'si, oyun yolu ile oyuncaklar ve bebekler kullanarak çocuğun hazırlanması gibi yöntemler tercih edilmektedir $(15,16,19)$. Bu yöntemlere ek olarak simülasyon uygulamaları ile çocuğa, ebeveynlere ve çocuğun bakımından sorumlu olan diğer bireylere eğitim verilebilmektedir $(20,21)$.

İlk planlanan ön eğitim, böbreğin yapısı ve görevleri, akut ve kronik böbrek yetmezliği ve nedenleri, kronik böbrek yetmezliği tedavi seçenekleri, hemodiyaliz ve periton diyalizinin avantajları, dezavantajları, transplantasyonun avantajları ve dezavantajları konularını içermelidir (1, 22).

Periton diyalizi eğitimi başlığında ise hasta ve ailesine genel hijyen kuralları, cerrahi yüz maskesi takma, el yıkama, eldiven giyme eğitimi verilmesi, periton diyalizinde kullanılan araç gereçlerin tanıtılması, asepsi-antisepsi-dezenfeksiyon-sterilizasyon vb. terimlerin öğretilmesi, değişim hazırlıkları, PD torbasına ilaç uygulama, kateter çıkış yeri kontrolü ve bakımı, beslenmenin önemi, sıv1 dengesi, komplikasyonların nedenleri ve yapılması gerekenler, evde kayıtların nasıl yapılacağ 1 , rutin kan testlerinin yapılması, ev ortamının düzenlenmesi, ev ziyareti amac1 ve önemi ile ilgili konularda bilgi verilmelidir (1). Son basamakta yer alan sürekli eğitim ise hasta ve ailesine verilen bu eğitimlerin, ev ziyaretleriyle sistematik olarak değerlendirilip tekrarlanmasını içermektedir $(22,23)$. Hasta ve ailesinin eğitimine ek olarak bakım hizmeti sunan ekibin de eğitimi önemlidir ve iyi sonuçlar elde etmek için aktif sürekli öğrenme ve yeniden eğitim gerekmektedir $(6,24)$.

Periton diyalizi sürecinde çocuk ve ailesinin yaşadığı ev tipi önemlidir. Evin koşulları, oda sayısı, temizliği, havalandırması uygun olmalıdır. Evde periton diyalizi için kullanılan ekipmanların yerleştirileceği ve değişimin yapılacağı ayrı bir oda olmalıdır.

Evin sağlık kuruluşuna uzaklığının değerlendirilmesi gerekir. Ev sağlik kuruluşuna erişimi engelleyecek bir uzakliktaysa bu ailenin periton diyalizi yöntemini kullanmasına onay verilmeyebilir. Ayrıca evde acil durumlarda yardım istemek için kullanabilecekleri bir telefon olmalıdır.

Evde elektrik, su şebekesi varlığ ile ilgili eksiklikler değerlendirilmelidir. Evde hayvan beslenip beslenmediği sorgulanmalıdır.

Bir diğer önemli konu ise ailenin, çocuğun durumuna tepkisinin nasıl olduğudur. Periton diyalizi tedavisinde ailenin desteği, duygu durumu, olanakları çok önemlidir. Bu tedavinin 
sürdürülebilmesi için ailenin ciddi bir sorumluluk alması ve bilinçli olması gerekmektedir.

Genel hatlarıyla yukarıda sorgulayabileceğimiz durumlar, çocuk ve ailesinin ev ortamında gözlemlenip değerlendirilmesiyle cevaplanmalıdır (1).

\section{SONUÇ}

Periton diyalizi normal böbrek fonksiyonlarının bazı işlevlerinin taklit edildiği bir tedavi yöntemidir. Her ne kadar çocuk ve ailesi için özgürlüğü arttırıcı, pratik ve güvenli bir yöntem olarak tercih edilse de ev ortamında uygulanan bir tedavi yöntemi olduğundan riskleri de beraberinde getirmektedir. Yapılan PD uygulamasının hijyenik ortamda sürdürülmesi ve işlemin teknik kurallara uygun şekliyle gerçekleştirilebilmesi için çocuk ve ailenin hemşirelik bakımı hizmetine ihtiyaç duyduklarını söylemek mümkündür. Hemşire bu nedenlerle hasta tedavisinin yönetilmesi ve sürdürülmesinde anahtar konumdadır. PD güvenli bir şekilde sürdürülmesi, çocuğun gelişebilecek komplikasyonlar ve enfeksiyonlardan korunabilmesi için iyi yapılandırılmış çocuk ve aile eğitimine ek olarak ev ziyaretleri ve gerekli denetimlerin yapılması önemlidir.

\section{Kaynaklar}

- Aydın, Z. Sürekli ayaktan periton diyalizi. http://www.nefroloji.org.tr/folders/file/surekli_ayaktan_periton_diyalizi.pdf, Erişim tarihi: 08.01.2020.

- Karadakovan A, Eti Aslan F. Dahili ve cerrahi hastalıklarda bakım. Karadakovan A, Eti Aslan F, eds. 2. Baskı. Adana: Nobel tip kitabevi; 2010. s. 316-320.

- Altaş, K. (2008). Periton diyalizi hastalarında saptanan peritonitlerde kültür sonuçları ile peritoneal lökosit sayısı ve klinik sonuçların ilişkisi. Yayınlanmamış uzmanlık tezi, Sağlık Bakanlığı Haseki Eğitim ve Araştırma Hastanesi Aile Hekimliği.

- Baş, S. Periton diyalizinde enfeksiyonlar ve tedavileri. http://www.ndthd.org.tr/images/periton-diyalizindeenfeksiyonlar-ve-tedavileri.pdf, Erişim tarihi: 01.02. 2020.

- Çavuşoğlu H, Çocuk sağlığı ve hemşireliği. Çavuşoğlu Heds. 8. Baskı. Ankara: Sistem ofset basımevi; 2011. s.316-321.

- Ballinger AE, Palmer SC, Wiggins KJ, Craig JC, Johnson DW et. al. Treatment for peritoneal dialysis-associated peritonitis. Cochrane Systematic Review 2014; 4(1), 99-110.

- Taşkopan, H. (2011). Periton Diyalizinde Kateter İle İlişkili Enfeksiyonlar. http://www.turkhipertansiyon. org/kongre2011/salon_2/2011-05, Erişim tarihi: 02.02.2020.

- Sözen Hasip T, Cesur S. 5 Dakikada Enfeksiyon Hastalıkları Değerlendirilmesi., İstanbul: Nobel Tıp Kitapevi; 2005. s. 310-312.

- Adıbelli Z. Akpolat T. Peritonitis. Offical Journal of the Turkish Society of Nephrology 2007; 16(2): 45-51.

- Danise J. Prevention of infection due to peritoneal dialysis. Nephrology Dialysis Transplant 2015; 30(9): 1461-1472.

- Uiterwijk H, Franssen FM, Kuipers J, Westerhuis R, Nauta LF. Glucose exposure in peritoneal dialysis 1s a significant factor predicting peritonitis. American Journal Nephrology 2020; 51(1), 237-243.

- Mokali AK, Sannaa AZ, Mutairi AF, Ahmed EA. Factors influencing occurrence of peritonitis in Saudi children on peritoneal dialysis. BMC Pediatrics 2020; 20(42), 2-7.

- Falbo P, Awdishu L, Ponce D, Balbi A. The role of plasma and dialysate vancomycin and amikacin levels in patients with peritoneal dialysis associated peritonitis. Kidney International Journal 2020; 1(1), 390-932.

- Morimoto K, Terawaki H, Washida N, Kasai T, Tsujimoto Y et. al. The impact of intraperitoneal antibiotic administration in patients with Peritoneal dialysis-related peritonitis: systematic review and meta-analysis. BMC Pediatrics 2020; 6(19), 2-6.

- Bramlett MD, Read D, Bethell C, Blumberg SJ. Differentiating subgroups of children with special health care needs by health status and complexity of health care needs. Matern Child Health Journal 2009; 13(2), 151-163.

- Cohen E,Kuo DZ, Agrawal R, et al Children with medical complexity: an emerging population for clinical and research initiatives. Pediatrics 2011; 127(3), 529-531.

- Fraser N, Hussain F, Connell R, Shenoy M. Chronic peritoneal dialysis in children. International Journal of Nephrology and Renovascular Disease 2015; 7(8), 125-137. 
- Lozano P, Houtrow A. Self-management in children and adolescents with complex chronic conditions. Pediatri Supporting 2018; 141(3), 233-241.

- Parker MG, Ibrahim T, Shaffer R, Rosner MH, Molitoris BA. The future nephrology workforce: Will there be one? Clin J Am Soc Nephrology 2011; 6(1), 1501-6.

- William JH, Huang GC. How we make nephrology easier to learn: Computer-based modules at the point-of-care. Medical Teaching Journal 2014; 36(1), 13-18.

- Dialysis Simulation. Center for Safety, Simulator and Advanced Learning Technologies. http://vam.anest. ufl.edu/simulations/dialysissimulation.php. Erişim tarihi: 11.05.2020.

- Taşkapan H, (2005). Periton Diyalizinde Kateter İlişkili Enfeksiyonlar. https://docplayer.biz.tr/79512045-Peritondiyalizinde-kateter-iliskili-enfeksiyonlar-prof-dr-hulya-taskapan-inonu-universitesi-tip-fakultesi-nefroloji-bilimdali.html, Erişim tarihi: 02.02.2020.

- Unal A, (2013). Periton diyalizinde infeksiyöz komplikasyonlar: riski nasıl azaltalım? http://www.nefroloji. org.tr/folders/file/unal7.pdf, Erişim tarihi: 20.01.2020.

- Cihangir N. Kubilay G. Sürekli Ayaktan Periton Diyalizi Uygulanan Çocuklarda Evde İzlemin Peritonit Görülme Sıklığına Etkisi. Journal of Hacettepe University School of Nursing 2006; 16(2): 2-11. 